\title{
Distribution of Fungi density and diversity in a Surface water of Epie Creek in Yenagoa Metropolis, Nigeria
}

\author{
Sylvester Chibueze Izah ${ }^{1}$, Glory Richard ${ }^{2 *}$ and Wisdom Ebiye Sawyer ${ }^{2}$ \\ ${ }^{1}$ Department of Microbiology, Faculty of Science, Bayelsa Medical University, Nigeria \\ ${ }^{2}$ Department of Community Medicine, Faculty of Clinical Sciences, Niger Delta University, Nigeria
}

\begin{abstract}
The ubiquitous nature of microorganisms makes them a frequent source of water resources contamination. This study evaluated the density and diversity of fungi in surface water of Epie creek in Bayelsa State, Nigeria. Triplicate samples of water were obtained in 5 locations in 4 different months ( 2 occurring in dry and wet season each). The water samples were examined following standard mycological procedures. Results showed that total fungi density ranged from $1.38-5.95 \times 10^{3} \mathrm{CFU} /$ $\mathrm{ml}$ and $0.81-6.02 \times 10^{3} \mathrm{CFU} / \mathrm{ml}$ in dry and wet season, respectively. Analysis showed significant variations $(p<0.05)$ across locations but no variation with respect to months. The fungi density exceeded the World Health Organization limit of $10^{2} \mathrm{CFU} / \mathrm{ml}$ for potable water. A total of 11 genera were identified in both seasons, and of these, Aspergillus flavus, Aspergillus fumigatus, Aspergillus niger and Penicillum species had the highest occurrence in both seasons. Other fungi isolated include Alternaria alternate, Aspergillus terreus, Cladosporium cladosporioides, Fusarium oxysporum, Microsporum canis, Mucor amphibiorum, Candida, Cryptococcus, Geotrichum and Sepedonium species. The isolates may have emanated from human activities in the creek/runoff in wet season. Most of the isolates are opportunistic and potentially detrimental to public health. Accordingly appropriate technological treatment of the water body is required to meet its various usages.
\end{abstract}

\section{Introduction}

Water is a fundamental resource needed for human existence because it's not only necessary for human growth but also crucial for agriculture, domestic and other industrial purposes. In many developing nations such as Nigeria, three main water sources are available viz: groundwater (borehole, spring etc), surface water (rivers, stream, creek, creeklets etc) and rainwater. Surface water is an important source of potable water to several families in Nigeria especially in the coastal areas where access to ground water is limited [1].

Due to indiscriminate disposal, wastes from agriculture eg insecticides (sniper), industrial chemicals and leachates from waste dump result in contamination surface water and also ground water in areas with high water table. According to Asingbi et al. [2], the distribution and movement contaminants depends on rainfall pattern, depth of water table, distance from the source of contamination and soil properties. In the Niger Delta region Nigeria, surface water contamination occurs mainly from human activities such as oil and gas exploration either through artisanal or motorized processes, dredging as well as unsustainable waste management practices and water transportation among others [3]. In addition, other smaller water bodies such as creeks, creeklets and rivulets serve as waste dump in many areas in the Niger Delta especially in Bayelsa State.

Water quality assessment is often carried out to ascertain the level of contamination in water resources and show the suitability of the water for human use in different settings [4]. The characteristic of the wastes that is deposited in surface water has the tendency to alter the physicochemical and microbial properties of the receiving ecosystem [4]. Some of the physical characteristics commonly identified are colour and turbidity. Also, microbes (bacteria, fungi, viruses and even protozoa) being microscopic in nature cannot be seen without the aid of lenses $[4,5]$. Some of the microbes isolated in surface water serve as an indicator organism especially certain species of bacteria. In addition, several infectious diseases are associated with poor water quality [6].

In Bayelsa State, several studies have been carried out with respect to the bacteriological quality of surface water resources including Epie creek [7], Taylor creek [8], Ikoli Creek [9], Nun River at Amassoma axis [10], Orashi river at Mbiama axis [11] but information about the mycological quality of Epie creek is scanty in literature. Therefore, the study focused on the mycological quality of surface water of Epie creek in Bayelsa State, Nigeria.

\section{Materials and Methods}

\section{Study area}

The study was conducted in Epie creek in Yenagoa metropolis, Bayelsa State, Nigeria. The creek has its route outside the metropolis. The creeks receive wastes from differences sources [12] including bathroom and kitchen effluents [7]. About 20 years ago, the water from the creek was used for drinking, bathing, recreational and transportation activities [12], but now the use of the water for domestic purposes has reduced drastically. For instance, a study conducted by Koinyan et al. [13] shows that $7.5 \%$ of residents of the metropolis (especially in Igbogene, Akenfa, Edepie, Swali, Biogbolo and Amarata) use surface water, while the rest use ground water $(89.20 \%$ and rainwater $(3.30 \%)$. The metropolis experiences a tropical monsoon climate with two

${ }^{\star}$ Correspondence to: Glory Richard, Department of Community Medicine, Faculty of Clinical Sciences, Niger Delta University, Wilberforce Island, Bayelsa State, Nigeria; E-mail: chivestizah@gmail.com

Key words: Environmental Health, Epie creek, fungi, microorganisms, water contamination

Received: March 10, 2021; Accepted: April 20, 2021; Published: April 27, 2021 


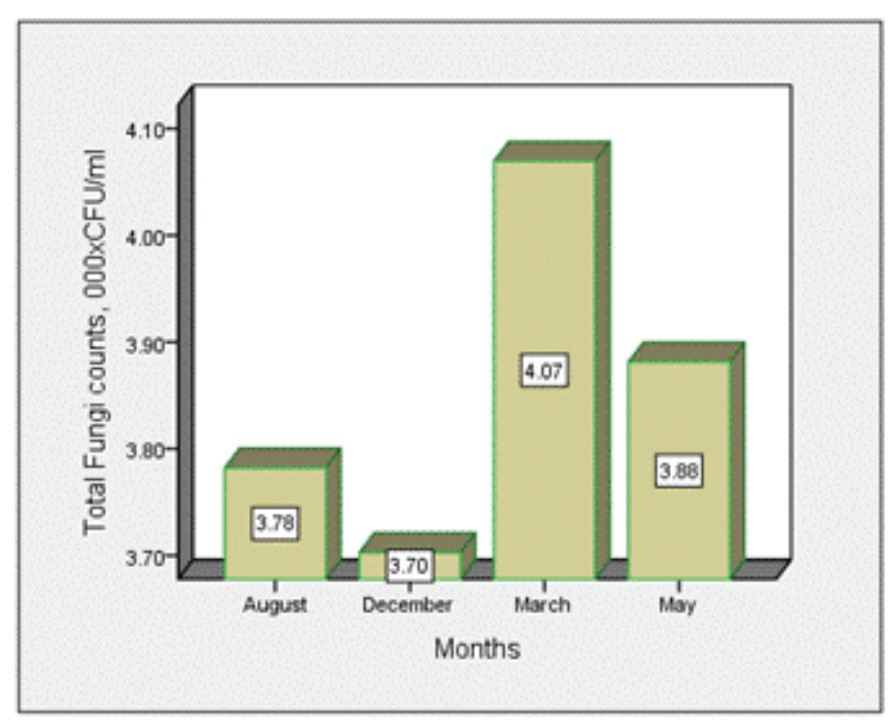

Figure 1. Distribution of total fungi counts across the various months of study

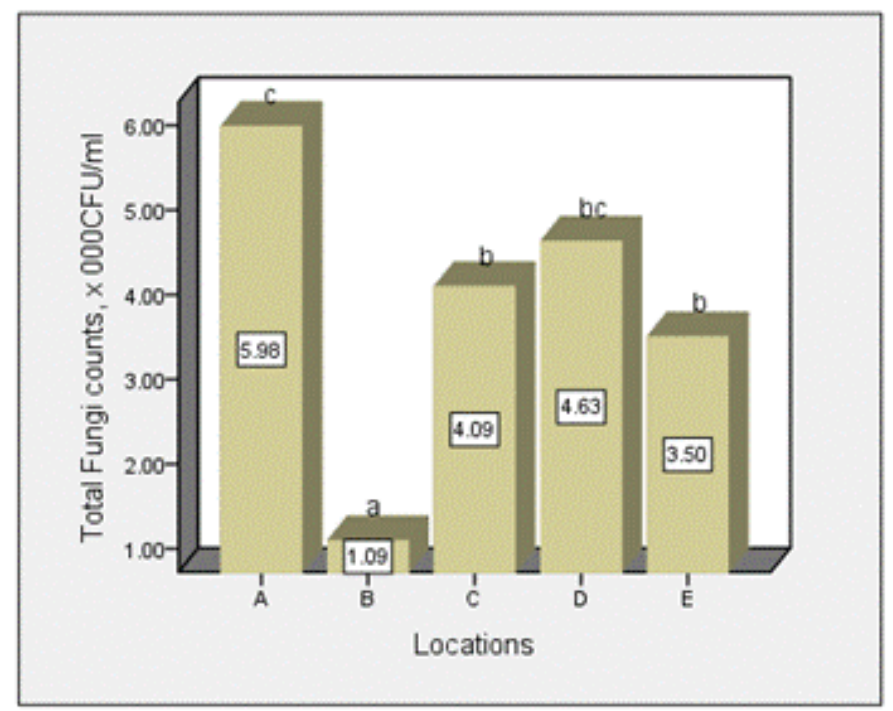

Figure 2. Distribution of total fungi counts across the various location of study

predominant seasons viz: rainy and dry with monthly temperature of around $28^{\circ} \mathrm{C}$, relative humidity of over $70 \%$ and mean annual rainfall of about $3,000 \mathrm{~mm}[6]$.

\section{Sample collection}

Triplicate water samples were collected from 5 locations in Epie creek in Yenagoa metropolis in 4 months viz: 2 in dry (December 2016 and March 2017) and wet season (May and August 2017). A total of 60 samples were collected over the period. The samples were collected using sterile bottles, labelled and preserved with ice bag prior to analysis.

\section{Enumeration of fungi counts}

The density of the fungi was enumerated using Potato Dextrose Agar prepared according to the manufacturers guide. The water samples were serially diluted and plated following the pour plate method described by Pepper and Gerba [14] and Benson [15]. The plated water sample in agar was incubated at $30^{\circ} \mathrm{C}$ for 5 days. The resultant colonies were enumerated and expressed as colony forming units (CFU)/ml of the sample.

\section{Identification of the fungi counts}

Macroscopic/ colonial and microscopic characteristics of the identified fungi were instrumental to their identification. Microscopic characteristics of the mould was determined using the wet mount preparation method, and Lactophenol cotton blue was used as the identification stain as previously described by Pepper and Gerba [14], Benson [15]. Also, yeasts were identified following the Colony morphology, Cellular morphology, Germ tube test, Slide culture, Sugar assimilation, motility tests as previously described by Onuorah et al. $[16,17]$. Also, the carbon assimilation test was carried out the method described by Kurtzman and Fell [18] and as applied by Iwuagwu and Ugwuanyi [19] and Izah et al. [20]. The resultant characteristics of the isolates were compared using the guide provided by Ellis et al. [21], Benson [15].

\section{Statistical analysis}

The statistical analysis was carried out using SPSS version 20. Twoway analysis of variance was carried out at $p=0.05$, and Waller-Duncan test statistics was used to discern the source of the observed variation. The frequency of isolates was presented in percentages, and bar charts used for all data.

\section{Results and Discussion}

The distribution of total fungi counts across the various location and months in surface water of Epie creek is shown in Figures 1 and 2 respectively. The density of total fungi across the months of study ranged from $3.70 \times 10^{3} \mathrm{CFU} / \mathrm{ml}$ (December) $-4.07 \times 10^{3} \mathrm{CFU} / \mathrm{ml}$ (March). There was no significant difference $(p=0.952)$ across the various months. The total fungi density across the various locations ranged from $1.09 \times 10^{3} \mathrm{CFU} / \mathrm{ml}$ (Location $\mathrm{B}$ ) $-5.98 \times 10^{3} \mathrm{CFU} / \mathrm{ml}$ (Location A). There were significant variations $(p=0.000)$ across the various location. Waller Duncan multiple range test statistics showed that there was no significant difference between Locations C, D and $\mathrm{E}$, and between Location A and D. There were significant interactions between the months and locations $(p=0.002)$.

The overall distribution of total fungi counts across the various months of study is shown in Figure 3. The mean values of total fungi for the various months ranged from 1.41-6.70 $\times 10^{3} \mathrm{CFU} / \mathrm{ml}$ (December),

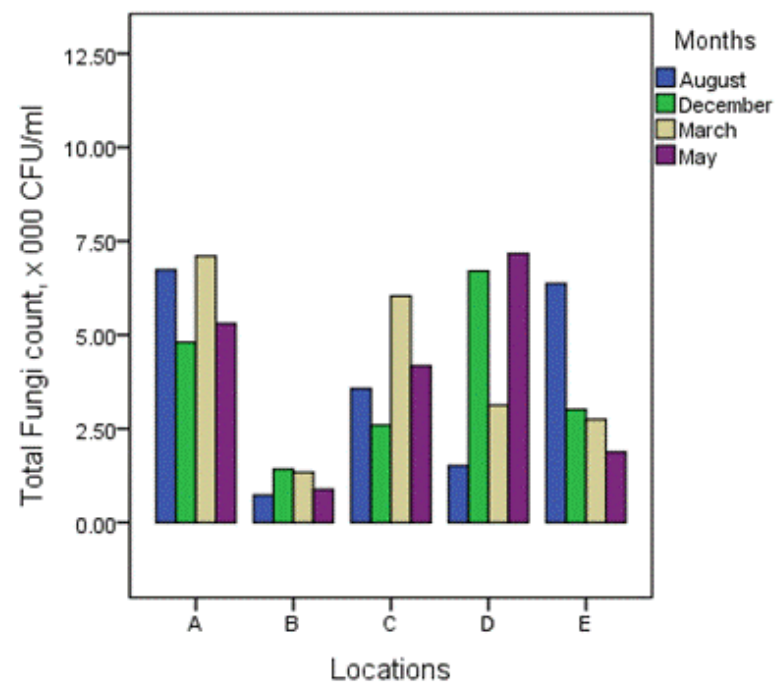

Figure 3. Overall distribution of total fungi counts across the various months of study 


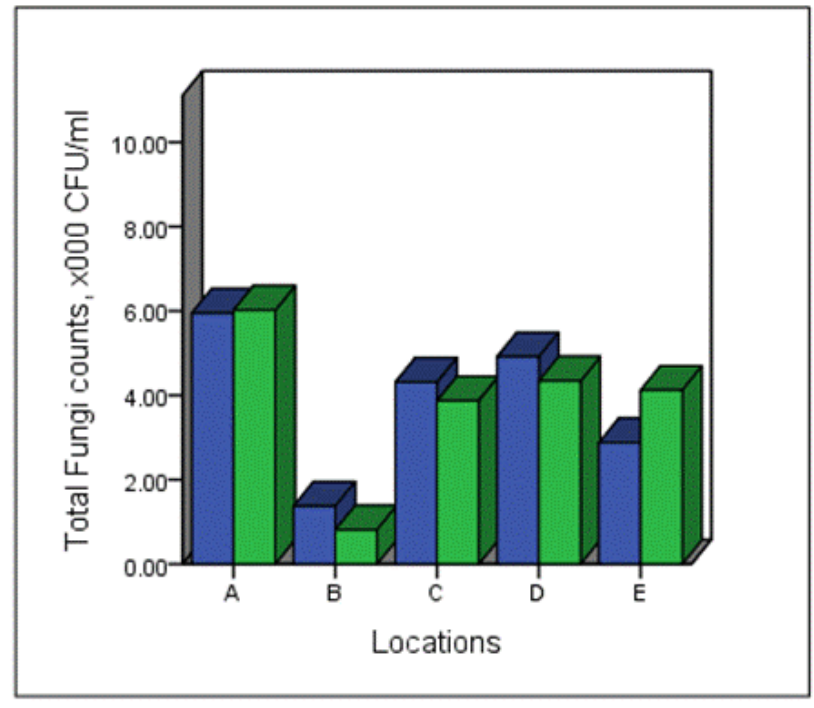

Figure 4. Seasonal distribution of total fungi counts across the various location of study

$1.34-7.10 \times 10^{3} \mathrm{CFU} / \mathrm{ml}$ (March), $1.88-7.17 \times 10^{3} \mathrm{CFU} / \mathrm{ml}$ (May) and 0.73-6.73 $\times 10^{3} \mathrm{CFU} / \mathrm{ml}$ (August) (Figure 3). On overall, values in dry and wet season ranged from $1.38-5.95 \times 10^{3} \mathrm{CFU} / \mathrm{ml}$ and $0.81-6.02 \times$ $10^{3} \mathrm{CFU} / \mathrm{ml}$, respectively (Figure 4 ).

The significant difference observed in the various locations may be attributed to difference in the level of anthropogenic activities in the creek all year round. The creek is known to receive varying waste emanating from household and agricultural settings. The absence of significant variation across the various months of study suggests uniformity in anthropogenic activity along the creek, though apparent difference exists. Furthermore, fungi density exceeded the World Health Organization (WHO) and United States Environmental Protection Agency (USEPA) limit of $10^{2} \mathrm{CFU} / \mathrm{ml}$ as specified by Duke et al. [22].

The values recorded in this study had some similarity with previous studies on water quality of some surface water in the Niger Delta. The value of total fungi ranged from $3.0 \times 10^{3}-3.7 \times 10^{4} \mathrm{CFU} / \mathrm{ml}$ in Otamiri river, Imo state [23], $2.1 \times 10^{3}-7.8 \times 10^{5} \mathrm{CFU} / \mathrm{ml}$ in Otamiri stream, Imo State [24], 2.12-2.22 $\times 10^{2} \mathrm{CFU} / \mathrm{ml}$ in a Surface water in Krakrama community, Rivers state [25] and lower than values from Ogbekpan and Ikpoba Rivers, Edo state [26] which range from 3.10-3.20 × $10^{5}$ $\mathrm{CFU} / \mathrm{ml}$ in). The variations observed could be due to difference human activities in the water ways. According to Abadom and Nwankwoala [4], the main anthropogenic activities that could pose severe risk to the water resources include oil and gas activities and associated leakages and pipeline corrosion, open dumping, leakages from septic tanks and effluents from industries.

The distribution and occurrence of the isolates across the various locations is shown in Figures 5-10 for location A, B, C, D and E, respectively. The occurrence rate of the isolates across all the locations was not season dependent. The overall seasonal distribution of the fungi isolates found in surface water of Epie creek in Yenagoa, Bayelsa State is shown in Figure 10. The occurrence of Alternaria alternate, Aspergillus flavus, Aspergillus fumigatus, Aspergillus niger, Aspergillus terreus, Candida species, Cryptococcus species, Geotrichum species, Cladosporium cladosporioides, Fusarium oxysporum, Microsporum canis, Mucor amphibiorum, Sepedonium species and Penicillum species were $2.97 \%, 18.64 \%, 16.53 \%, 19.07 \%, 1.69 \%, 3.81 \%, 0.00 \%, 0.00 \%$, $3.39 \%, 9.75 \%, 5.51 \%, 4.24 \%, 1.27 \%$ and $13.14 \%$, respectively for dry season and $7.92 \%, 16.42 \%, 12.90 \%, 13.49 \%, 0.88 \%, 3.23 \%, 1.76 \%$, $0.59 \%, 5.87 \%, 8.21 \%, 9.97 \%, 4.40 \%, 2.35 \%$ and $12.02 \%$, respectively for wet season. These fungi isolates may have stemmed from anthropogenic activities and run-off/ flood water during the wet season thereby making the water unit for domestic use.

Some of the fungi isolates identified in this study have been reported in some other studies on surface water in some part of the Niger Delta region of Nigeria. For instance, Braide et al. [24] reported the occurrence Penicillium, Geotrichum, Aspergillus, Mucor, Rhizopus species, Candida albicans and Saccharomyces cerevisiae in Otamiri stream, Imo State. Idibie et al. [26] reported Trichoderma, Mucor, Penicillium and Aspergillus species. Amadi et al. [25] reported Penicillium, Aspergillus, Mucor species, Fusarium solani, Candida albicans and Saccharomyces cerevisiae in a surface water in Krakrama community in Rivers state. Based on the occurrence/distribution, Aspergillus species had the highest, a trend that have been reported in aero environment of a dumpsite [27], Market area [28]. Also, some of the fungi isolated in this study are known to produce mycotoxins that may be detrimental

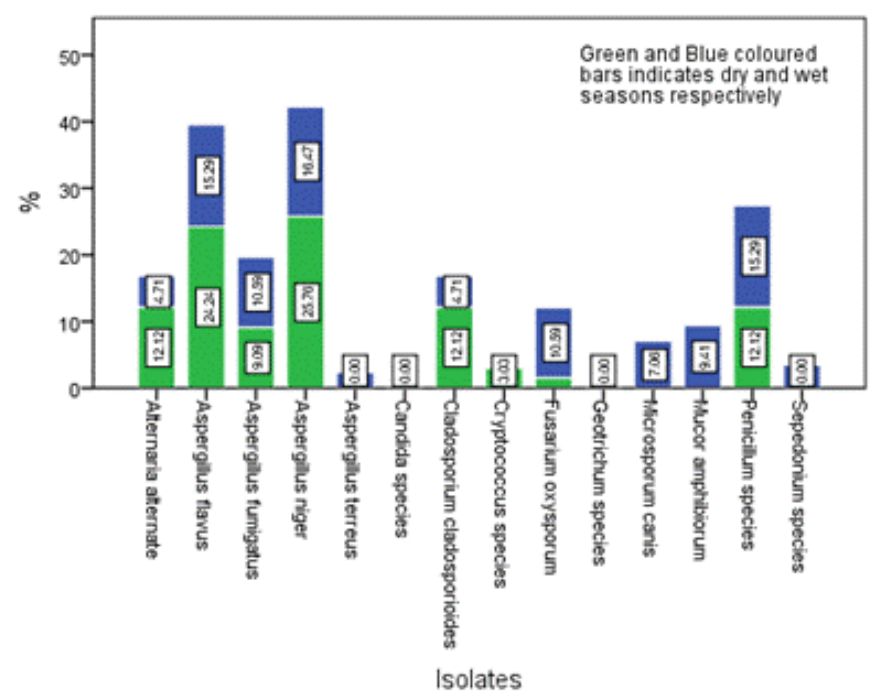

Figure 5. Seasonal occurrence of the isolates in Location A in the study area

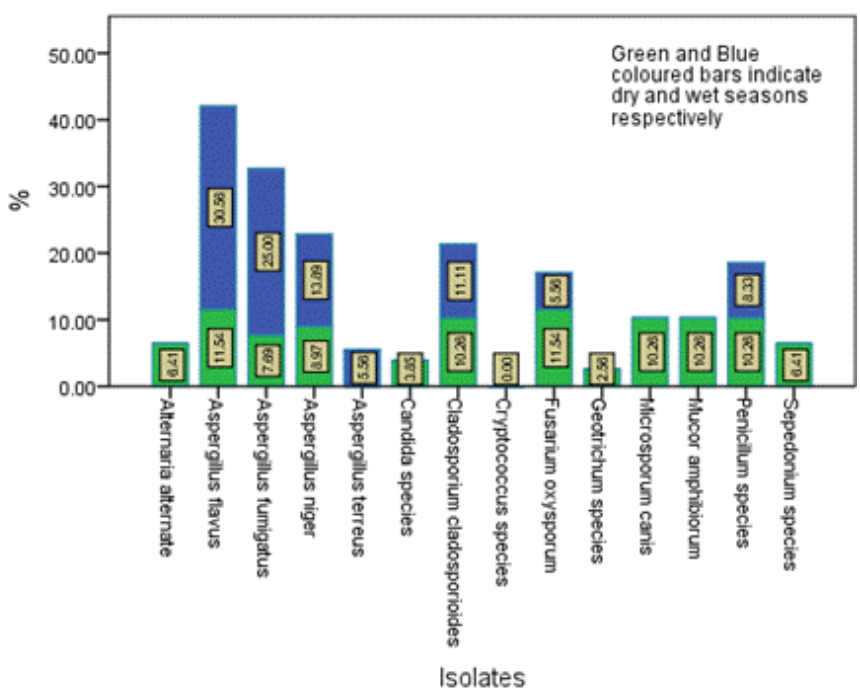

Figure 6. Seasonal occurrence of the isolates in Location B in the study area 
to human health $[27,29,30]$, while are known to cause different types of diseases especially in immune compromised individuals [27,31]. In addition, some of the isolates identified are not commonly found in surface water, hence opportunistic pathogens due to anthropogenic activities and/ or flooding event during the wet season.

\section{Conclusions}

The study which investigated the mycological quality of surface water found that the mycological quality often exceeded the WHO and USEPA limits of $102 \mathrm{CFU} / \mathrm{ml}$. The lack of discrepancies in fungi density across the months of study is an indication of the homogenous environmental conditions all year round. However, variations in fungi density across the locations are an indication of differences in human activities along the creek. Some of the isolates are opportunistic pathogens, an indication of anthropogenic impact on the surface water quality of Epie creek in Bayelsa State, Nigeria. Based on the results of the study, there is need for proper treatment of the water body if domestic use is intended.

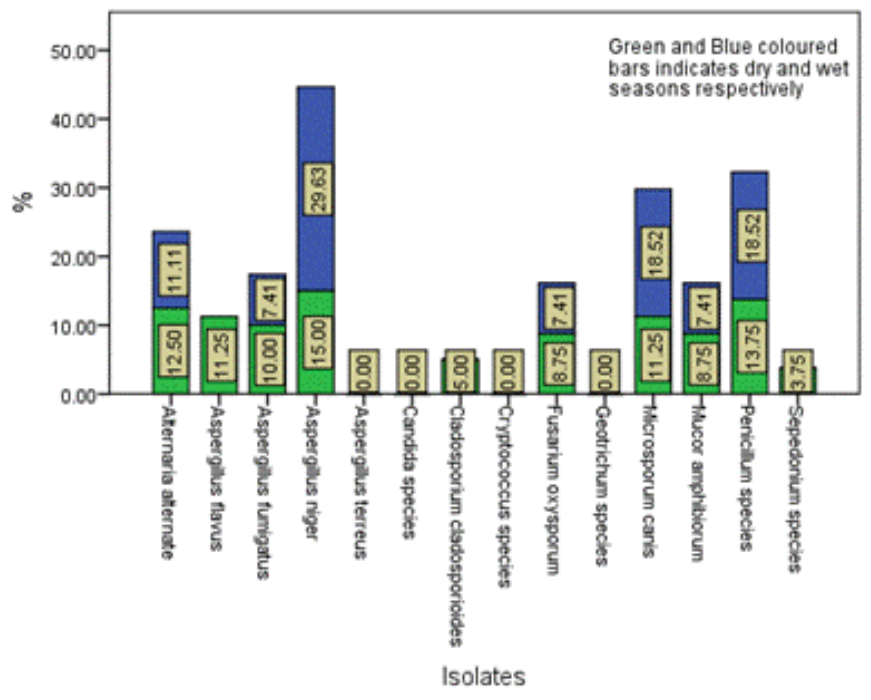

Figure 7. Seasonal occurrence of the isolates in Location C in the study area

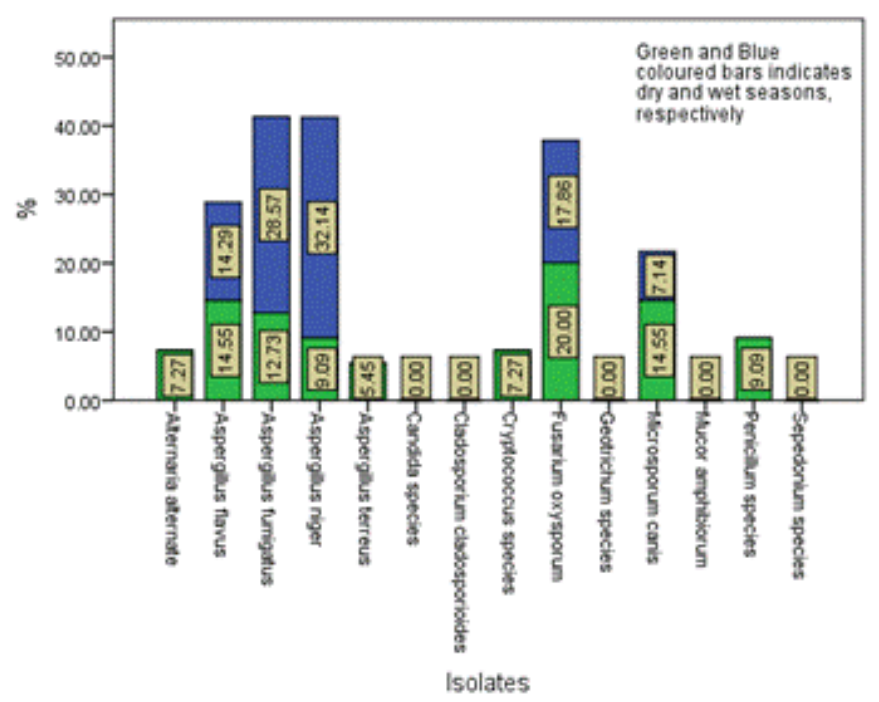

Figure 8. Seasonal occurrence of the isolates in Location D in the study area

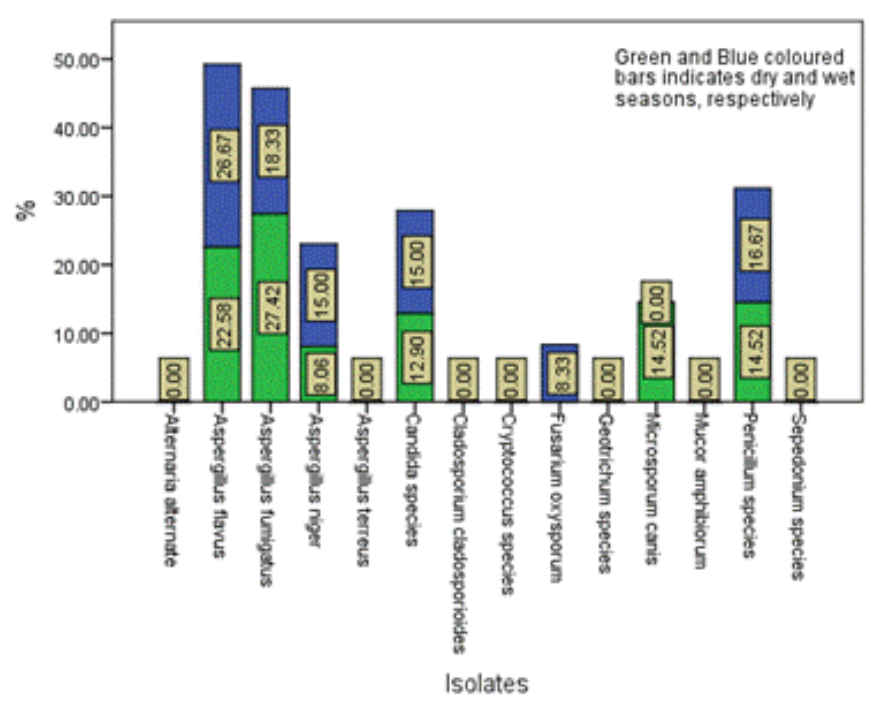

Figure 9. Seasonal occurrence of the isolates in Location E in the study area

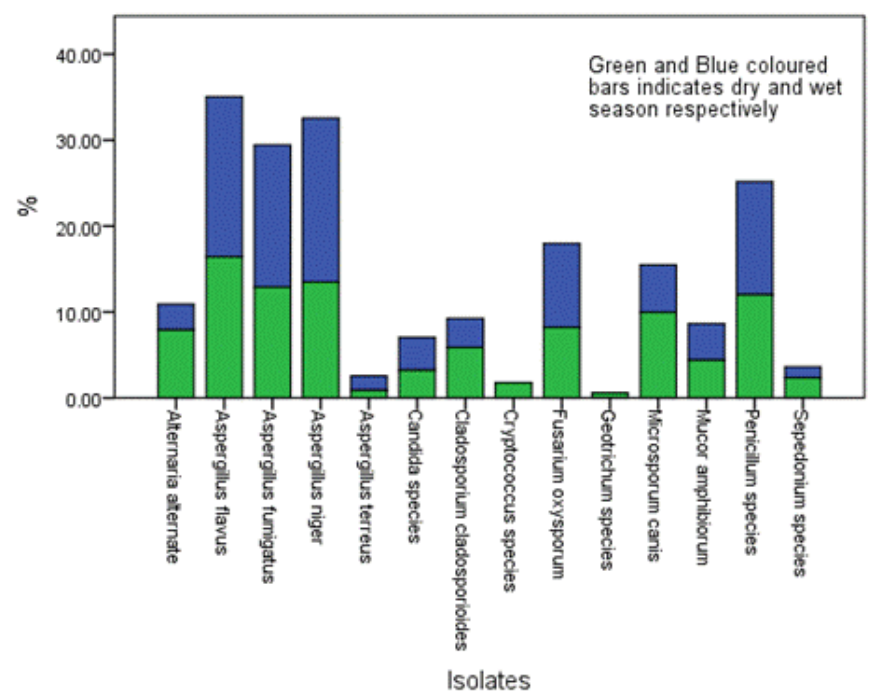

Figure 10. Overall seasonal distribution of fungi in surface water of Epie creek in Yenagoa, Bayelsa State, Nigeria

\section{References}

1. Izah SC, Chakrabarty N, Srivastav AL (2016) A Review on Heavy Metal Concentration in Potable Water Sources in Nigeria: Human Health Effects and Mitigating Measures. Exposure Health 8: 285-304.

2. Asingbi T, Durowoju O, Olusola A, Obateru R (2020) Variations in Physico-Chemical Properties of Shallow Groundwater Aquifers Across Rural-Urban Differentials. Analele Universităţii din Oradea, Seria Geografie 30: 53-64.

3. Seiyaboh EI, Izah SC (2017) Review of Impact of Anthropogenic Activities in Surface Water Resources in the Niger Delta region of Nigeria: A case of Bayelsa state. Int $J$ Ecotoxicol Ecobiol 2: 61-73.

4. Abadom DC, Nwankwoala HO (2018) Investigations of Physico-Chemical Composition of Groundwater in Otuoke and Environs, Bayelsa State, Nigeria. Int $J$ Environ Sci Nat Res 9: 555752.

5. Nwankwo CEI, Barika PN, Akani NP, Amadi ON (2020) Physicochemical and Mycological Examination of Groundwater (Well Water) in Rumuosi Community, Rivers State, Nigeria. Res J Microbiol 15: 82-89.

6. Ohwo O (2019) Analysis of households' vulnerability to waterborne diseases in Yenagoa, Nigeria. J Water Sanitation Hygiene Development 9: 71 -79. 
7. Ben-Eledo VN, Kigigha LT, Izah SC, Eledo BO (2017) Bacteriological Quality Assessment of Epie Creek, Niger Delta Region of Nigeria. Int J Ecotoxicol Ecobiol 2: $102-108$.

8. Seiyaboh EI, Youkparigha FO, Izah SC, Mientei K (2020) Assessment of bacteriological characteristics of surface water of Taylor creek in Bayelsa state, Nigeria. Noble Int $J$ Scientific Res 4: 25-30.

9. Seiyaboh, EI, Izah SC (2017). Bacteriological assessment of a tidal creek receiving slaughterhouse wastes in Bayelsa state, Nigeria. J Adv Biol Biotechnol 14: 1-7.

10. Seiyaboh EI, Izah SC, Bokolo JE (2017) Bacteriological quality of water from river nun at Amassoma Axises, Niger Delta, Nigeria. ASIO J Microbiol Food Sci Biotechnological Innovations 3: 22-26.

11. Seiyaboh EI, Kolawole EP (2017) Diversity and Levels of Bacteriological Contamination in Orashi River, Mbiama Community, River State, Nigeria. $J A d v$ Microbiol 4: 1-6.

12. Izonfuo LWA, Bariweni AP (2001) The effect of urban runoff water and human activities on some physico-chemical parameters of the Epie Creek in the Niger Delta. $J$ Appl Sciences Environmental Management 5: 47-55.

13. Koinyan AA, Nwankwoala HO, Eludoyin OS (2013) Water resources utilization in Yenagoa, Central Niger Delta: Environmental and health implications. Int $J$ Water Resources Environmental Engineering 5: 177-186.

14. Pepper., I.L., Gerba., C.P. 2004. Environmental Microbiology. A Laboratory Manual. 2nd edn. Oxford: Elsevier Academic Press.

15. Benson., H.J. 2002. Microbiological Applications: Laboratory Manual in General Microbiology/complete version. 5th edn. New York: McGaraw-Hill.

16. Onuorah S. Obika I, Orji M, Odibo F (2015) Microbial contaminants in the commercia aviation fuel obtained from Benin City Airport, Nigeria. Univ J Microbiol Res 3: 31-35.

17. Onuorah S, Elesia R, Odibo F (2016) Mycology of Hand-dug Shallow Water Wells in Awka Metropolis, Anambra State, Nigeria. Adv Zoology Botany 4: 17-22.

18. Kurtzman C.P., Fell J.W. 1998. The Yeasts: A Taxonomic Study. 4th edn. Amsterdam: Elsevier Science.

19. Iwuagwu JO, Ugwuanyi JO (2014) Treatment and Valorization of Palm Oil Mill Effluent through Production of Food Grade Yeast Biomass. J Waste Manag 2014: 439071.
20. Izah SC, Bassey SE, Ohimain EI (2017) Changes in the Treatment of Some PhysicoChemical Properties of Cassava Mill Effluents Using Saccharomyces cerevisiae. Toxics 5: 28. [Crossref]

21. Ellis D., Davis S., Alexiou H., Handke R., Bartley R. 2007. Descriptions of Medical Fungi. 2nd Edn. Adelaide: Nexus Print Solutions.

22. Duke M, Antai SP, Tiku DR (2018) Microbiological Quality Assessment And Physicochemical Analysis Of Selected Major Streams And Rivers In Calabar Municipality. World J Pharmaceutical Med Res 4: 287-298.

23. Duru MKC, Nwanekwu KE, Adindu EA, Odika PC (2012) Heavy metal and bioload levels of Otamiri river, Owerri, Imo State, Nigeria. Arch Appl Sci Res 4: 1002-1006.

24. Braide W, Nwachukwu J, Adeleye SA, Egbadon EO (2016) Effects of gas flaring on the physicochemical and microbiological quality of water sources in Egbema, Imo State, Nigeria. Int Let Nat Sci 56: 7-13.

25. Amadi LO, Berembo BT, Wemedo SA (2020) Microbiological and Physicochemical Properties of Krakrama (Brackish) Water in Rivers State, Niger Delta, Nigeria. Acto Scientific Microbiol 3: 123-132.

26. Idibie OC, Oviojie OE, Isalar OF, Emoghene AO (2018) Comparative Microbial Analysis of Borehole Water and other Sources of Water in Benin Metropolis, Edo State. J Environm Sci Public Health 2: 232-242.

27. Izah SC, Richard G, Aseibai ER (2021) Public Health implications of Fungi-aerosol contamination around a major dumpsite in Bayelsa State, Nigeria. $J$ Environm Treatment Techniques 9: 458-462.

28. Richard G, Aseibai ER (2021) Seasonal variation in mycological quality of air environment around a major market along East-West road in Bayelsa State, Nigeria. Int $J$ Healthcare Med Sci 7: In press

29. Orutugu LA, Izah SC. and Aseibai ER (2015) Microbiological quality of Kunu drink sold in some major markets of Yenagoa Metropolis, Nigeria. Continental J Biomed Sci 9: 9-16.

30. Ineyougha ER, Orutugu LA, Izah SC (2015) Assessment of Microbial Quality of Smoked Trachurus trachurus sold in some Markets of Three South-South States of Nigeria. Int J Food Res 2: 16-23.

31. Richard G and Aseibai ER (2021) Assessment of Mycological Quality of Groundwater In Yenagoa Metropolis, Bayelsa State, Nigeria. Sumerianz J Med Healthcare 4: 76-81.

Copyright: @2021 Izah SC. This is an open-access article distributed under the terms of the Creative Commons Attribution License, which permits unrestricted use, distribution, and reproduction in any medium, provided the original author and source are credited. 